\title{
DESARROLLO Y COHESIÓN EN LA PENÍNSULA IBÉRICA: EL PROBLEMA DE LA ORDENACIÓN TERRITORIAL
}

\author{
Julián Mora Aliseda ${ }^{1}$
}

O planeamento territorial e em geral as orientações de ordenamento do espaço aparecem cada vez mais como uma via privilegiada de atenuação das assimetrias regionais e locais, em ordem a uma progressiva perequação territorial, realizadora da coesão económico-social associada à realização de um desenvolvimento equilibrado e sustentável.

A estratégia Territorial Europeia, ou Esquema de Desenvolvimento do Espaço Comunitário (ETE/EDEC), cuja aplicação obrigatória resulta de compromissos multilaterais globais dos Estados da UE, e não do assumir de atribuições novas pela União, expressa orientações fundamentais para a integração nas políticas nacionais e infra-estatais, sem pôr em causa as atribuições das entidades existentes, normalmente competência dos Estados.

A articulação territorial interadministrativa, respeitando o princípio da subsidiariedade, deve construir-se na cooperação, por um lado, entre todas as administrações incumbidas das políticas sectoriais (cooperação horizontal) e, por outro, entre estas e as administrações competentes para a planificação física, a todos os níveis, tendo sempre presente as políticas traçadas, quer no âmbito da União Europeia, quer no das autoridades de planificação supra-ordenadora, quer ainda nas de escala transnacional, regional ou municipal (cooperação vertical e coordenação global). Esta articulação, que é a chave para uma política de desenvolvimento territorial integrado, configura uma mais-valia em relação à implementação isolada das políticas sectoriais, ou mesmo estratégicas elaboradas ao nível da própria escala, impondo não só, política e administrativamente, a definição das fronteiras da subsidiariedade vertical como também a fundamental construção e afirmação, permanente e institucional, da solidariedade interestatal e interpeninsular, neste campo do desenvolvimento económico e territorial. Esses quesitos estão hoje integrados plenamente no Tratado de Lisboa como vectores conjuntos da coesão económico-social da União, o que exige ampla abertura a múltiplas cooperações, devidamente estruturadas e não meramente casuísticas.

Todas estas questões são analisadas com o maior rigor pelo Professor Fernando dos Reis Condesso, catedrático da Universidade Técnica de Lisboa, no seu livro, publicado en castelhano, sob o título Desarrollo y cohesión en la Península Ibérica: El problema de la Ordenación Territorial, Ediciones Erasmus, Barcelona, 2010². Este livro vai tornar-se num

1 Professor Catedrático Convidado da Universidade Técnica Lisboa. E-mail: jmora@unex.es

2 Fernando dos Reis Condesso (2010) Desarrollo y cohesión en la Península Ibérica: el problema de la ordenación territorial. Barcelona, Erasmus. 
manual de referência para todos os profissionais (geógrafos, arquitectos, juristas, engenheiros, sociólogos, economistas, etc.) que se debatam no dia a dia com os problemas derivados da planificação espacial (urbanismo, infraestruturas, equipamentos, políticas e directrizes). A obra aparece num momento muito oportuno, já que, no seu artigo $3 .^{\circ}$, o Tratado de Lisboa, que entrou em vigor a 1 de Dezembro de 2009, estabelece a coesão territorial como um objectivo explícito para a futura política europeia de coesão. Isto é, as políticas territoriais alcançam pela primeira vez um nível de importância similar às políticas de coesão económica e social, constituindo um dos três pilares básicos do Estado de Bem-estar da União Europeia.

Para além da citada oportunidade do livro, há que destacar a capacidade do autor, um dos maiores especialistas europeus, para abordar as soluções de muitos dos problemas relativos ao ordenamento do território no espaço peninsular. De facto, ele une à sua faceta académica de catedrático de direito administrativo, uma vertente científica como doutor em geografia, com experiência política nacional e internacional como deputado à Assembleia da República e eurodeputado, durante cerca de década e meia, o que lhe permitiu dissecar com precisão a complexidade das inter relações do tema. Por conseguinte, saudamos vivamente esta oportuna e útil publicação. 